Кроме того, авторы при необходимости могут использовать другие (не указанные) заголовки и подзаголовки разделов. Сведения об авторе и его (их) подпись (подписи) должны быть напечатаны в конце рукописи, в соответствии с которой автор юридически подтверждает своё личное согласие, а в случае опубликования статьи, также личное согласие на размещение статьи и онлайн-информации об авторе в Российском индексе научного цитирования (РИНЦ) на платформе Научной электронной библиотеки РФ и/ или онлайн-публикации на веб-сайте журнала. Страница с личными подписями авторов может быть представлена в виде скан-копии в формате *.pdf или в любом отдельном графическом файле.

12. И, наконец, весь отправляемый материал должны быть заархивирован в единый архив ( ${ }^{*}$.zip, *.rar, *.7-Zip) и должен содержать следующие файлы с именами:

а. Файл, который содержит текст статьи, рекомендуется называть фамилией автора, а именно: Petrov_doc или Petrov_i_soavt.doc. На последней странице этого файла следует поместить информацию об авторе(ах) и скан-изображение(я) подписи автор(ов).

б. Файл(ы), содержащие таблицы должны быть названы, например, Petrov_Tabl_1.doc, Petrov_Tabl_2.doc, и т.д.

в. Файл(ы), содержащий(е) иллюстрации должны быть названы, например, Petrov_Ris_1.jpg, Petrov_Ris_2.jpg или Petrov_Ris_A.jpg, Petrov_Ris_В.jpg и т.д.

г. Файл(ы), содержащий(е) обозначения для иллюстраций: Petrov_Obozn_Ris_1.doc, Petrov_Obozn_Ris_2.doc, и т.д.

д. Если имеется отдельная скан-копия последней страницы текста статьи с информацией об авторе(ах) и подписью(ми) автора(ов), то должен быть также соответствующий файл с названием: Petrov_Author_Inform.pdf.

е. Файл скан-копии квитанции об оплате: Petrov_Oplata.pdf или Petrov_Oplata.jpg.

ж. Дополнительные документы и материалы по инициативе и усмотрению автора (статистические файлы, дополнительные таблицы, рисунки, фотографии, сертификаты грантов и т.д.), которые необходимы для подтверждения актуальности и значимости исследования.

13. Автор(ы) должен(ы) быть готов(ы) к любой просьбе редакторов или рецензентов представить дополнительные документы и информацию по статье.

14. В случае некорректного перевода на английский язык названия статьи, реквизитов авторов, резюме и ключевых слов, общего несоответствия резюме и списка литературы требованиям журнала, отсутствия транслитерации названия источников на кириллице на английский язык, редакция отказывает авторам в индексировании статьи и резюме во всех международных индексаторах, в связи с требованиями условий соответствующих договоров. При условии соблюдении всех остальных правил журнала статья может быть по решению редколлегии опубликована только в печатном варианте журнала без выставления интернет-версии статьи на веб-сайты журнала и научноэлектронной библиотеки e-library.ru (РИНЦ) и присвоения doi. Приоритетной является электронная версия журнала.

15. Вся электронная переписка автора(ов) и редакции имеет такую же юридическую силу, как и обмен соответствующими стандартными документами.

\title{
GUIDE FOR AUTHORS
}

The sent articles should be only original materials. The articles should be presented only on Russian or English languages. The editors do not accept articles which being prepared for publication or was already published in other publications.

1. Articles and other materials should be written in a good literary language without spelling and stylistic errors, carefully edited, correspond to the scientific style of speech and scientific terminology, do not require additional editing, or require only minimal amendments. All special terms including terms on Latin should accurately correspond to the international nomenclature of terms: Terminologia Anatomica (TA), Terminologia Histologica (TH) and 
Terminologia Embryologica (TE), International Classification of Diseases of 10th Revision and to other international standards of biomedical sciences. Names of plants according to the International Code of Nomenclature for algae, fungi, and plants (Melbourne Code, 2011) of International Association for Plant Taxonomy; Names of animals according to the International Code of Zoological Nomenclature (IV Edition, 2000) of International Commission on Zoological Nomenclature; Names of chemical substances and reagents according to the nomenclature of Chemical Abstracts Service Registry Number (CASRN) and International Union of Pure and Applied Chemistry (IUPAC) etc.

2. The Article and additional documents should be sent to editors only as electronic files to e-mail: morpholetter@yandex.ru, morpholetter@gmail.com. As an exception manuscripts, may be sent to the editors by regular mail (postal address see on home-page of the web-site of the journal) in two copies of the typewritten texts, printed on one side of a standard paper sheet of A4 (210x295 $\mathrm{mm}$ ) and (or) as computer text. In this case, always with the article simultaneously should be sent all additional materials (files) in electronic form according with the rules for authors on the relevant portable electronic flashcard or CD which must be put in a letter or in parcel.

3. The text is typed of the font of the type Times New Roman of 12th point in the text editor Microsoft Word or other similar text editor, the acceptable formats «document Word.doc (preferably *.docx) », ODF (*.odt), or the format of RTF, in an extreme case - «Text only.txt». The text is typed without additional formatting and the word wrap, the text should not be printed in capital letters, in bold, underlined or italicized, with use of signs a tabulation, etc. Mathematical and other symbols $( \pm, \approx, \alpha \beta \gamma \delta \lambda \mu \Pi, \Sigma, o, \hat{o}$ et al.) must be typed in Symbol font.

4. The content of the article should be (in the order of placement of text): the title of the article and the list of authors (surname and initials) in Russian language, the title of the article and the list of authors (surname and initials) in English language. Further, in the brackets and only on Russian language must specify the academic rank, surname and initials of the head of the department or laboratory, the title of the institution, the city and the main text of the article according to rubricating, which is indicate in section 5 (see bottom). If authors work in different organizations, you need to use the symbols $\left({ }^{*}\right.$ or 1,2$)$ and to correlate each author with his organization. The cover sheet is not required.

5. The text should consist of the following sections (the section title exactly as shown below): resume and no more five keywords in Russian, resume and no more five keywords in English; introduction; objectives; material and methods; results, discussion; conclusions; conflicts of interest, acknowledgements, references, author's information. We urge to place the author's information in the main text - after the list of references. For the determine of keywords should be used international thesauruses, such as e.g. Universal Decimal Classification, Medical Subject Headings (MeSH) of the National Library of Medicine (USA) and other. The summary should be structured in strict accordance with sections of the article (introduction, aim of the study, objects and methods, results, discussion, specific findings and conclusions). Titles of sections in the summary may be omitted. The total size of the summary is at least of 250 words and a maximum of 330 words.

6. In describing of the objects be required to indicate the size of observation group, age (age groups), sex (gender identity), the principles and procedure of formation of the observation group (random selection or others), species affiliation of microorganisms, plants or animals, the active substance in accordance with international requirements. Indication is mandatory about the observance of the principles of humane treatment of animals and about the abiding of the presence of the fundamental human rights procedures and legal requirements. Especially it is necessary to stipulate the procedure for obtaining of the autopsy or biopsy material and legitimate reasons for using it. In the study of anatomic museum preparations should indicate the sources of the information, the titles of the museum collection, of the ossuary and the appropriate permissions.

7. Methods (the anatomical technique of the prosection, the dissection and the preparation, the histological technique and the staining of preparates), equipment (including the title of the manufacturer), and all other procedures should be described as detailed as possible so that other researchers were able to reproduce the results. In the description of standard methods is 
recommended to refer to the source or regulations with the detailed description, at description of the new method recommend detailed present tools of manipulation and approaches, so that they also can be reproduced by other researchers. Statistical procedures (descriptive statistics, multivariate analysis methods) used statistical indicators their confidence limits and degree of likelihood of a testable hypothesis must be described in detail.

8. Tables should have its sequence number in order of the mention in the text of the article, but titles of tables not repeated in the text. All blank rows of tables should be marked with a dash or minus-sign. The font for the text of tables should be Times New Roman, font size at least $10 \mathrm{pt}$. Each table should be represented as a separate file. Places in the text of the article, in that should be placed tables, should be marked on the fields of the page in square frame with the tables number, or by means of words in the text of the article, such as "The location of the Table 1". More than 2 tables for publication are not accepted. Photo-tables and tables which was converted in files of pictures (*.bmp, *.jpg, *.png etc.) is not accepted. Editorial recommends using instead of tables charts, graphs, illustrations and micro photos of histological preparations. To indicate the differences in the data presented in the tables, you can use the following characters and symbols *, $* *, * * *, \dagger, \ddagger,+,++,+++$, and others.

9. Illustrations to the article should be provided in the form of graphic files TIFF ( ${ }^{*}$.tiff) or JPG (*.jpg ) with a resolution of at least 300 dpi with a width of $100 \mathrm{~mm}$ or more (i.e., one of the dimensions of the image should be at least 1200 pixels). The volume of illustrations - should be the minimum required and for the original papers should not exceed one page of the journal. The article must contain a reference to all the drawings as they are referred in the main text, starting since of the serial number one. Captions and their symbols should not be repeated in the text. All images are sent as separate files besides of the main text-file of the article. Besides that:

a. Graphs and charts should not include their titles, and should be marked by individual inscriptions. Titles of illustrations are sent as separate files (sheets), for each illustration - separate file of their title (as simple text file).

b. On the ultramicroscopic photos should be placed the scale, in the designations to micrographs - the common magnification or magnification of the ocular and lens, explanation of symbols, the method of staining or other processing of histological slides. The place in the text of the article, in that should be placed the Figures, should be marked on the fields of the paper in square frame with the illustration serial number, or by the words in the text, such as "Location of the Figure 1".

c. Designations on all Figures are required; they should not repeat the main text of the article, are provided on separate files (sheets) and should be numbered as the illustrations, respectively. In case in the Figures was used symbols, arrows, numbers or letters, then all must be deciphered in the designations, and should be presented in text-file of the title of the Figure (or as the handwritten notes on a hard paper), and should be made as the image file with a pattern on a separate file.

d. Electronic copies of drawings, diagrams, charts, photomicrographs, electronic photomicrographs should be available as separate files (Ivanov_fig1.tif and etc.).

e. The presence of illustrations in the text of the file of the article is not allowed.

f. Illustrations histological preparations are accepted only in color and in high resolution (of at least $300 \mathrm{dpi}$ and more).

10. References (bibliography) must be drawn up in common accordance with the rules of the National Library of Medicine of USA (Citing Medicine, 2th edition, http://www.nlm.nih.gov/citingmedicine and in end of the reference should be indicated their DOI or URL (if the presence). The numbering of sources is made to the prioritization in which they are mentioned as references in the text. Also references (bibliography) may be drawn up in accordance with the rules of the Russian State Standard 7.1-2003 (only for articles on Russian). All sources in Russian and in other languages using the Cyrillic alphabet should be printed as transliterated into English. The free transliteration can be done online on web-site www.translit.ru automatically. Replacement of titles of these sources on their titles which translated into English is not allowed. Editorial recommend the BGN/PCGN (British Standard) romanization system for 
Cyrillic texts in the English language, which was developed by the United States Board on Geographic Names (BGN) and by the Permanent Committee on Geographical Names (PCGN). Reference to the source is given in the text in square brackets. The numbering is determined by the order of citations of references in the text. In the text of the article must be used of the continuous numbering, starting with the number 1 . Beyond text references must be numbered.

Examples of different references for all articles (as in Russian and in English)

Printed journal article (all, without excluding, authors of the article should be indicated):

On Russian

Rassolov VN, Semenova GS, Bulanov SI. Organizatsiya limfoidnoy tkani v yazychnoy mindaline. Morfologicheskie vedomosti. 2015;23(2):84-89. DOI: (if it is).

On English

Steward AJ, Kelly DJ. Mechanical regulation of mesenchymal stem cell differentiation. J Anat. 2015; 227():717-731. DOI: 10.1111/joa.12243.

Open access journal article:

On Russian

Moroz VV, Golubev AM, Chernysh AM, Kozlova EK, Vasil'ev VYu, Gudkova OE, Sergunova VA, Fedorova MS. Izmeneniya struktury poverkhnosti membran eritrotsitov pri dlitel'nom khranenii donorskoy krovi. Obshchaya reanimatologiya. 2012;8(1):5. DOI:10.15360/1813-9779-2012-1-5

On English

Lamzin IM, Khayrullin RM. The quality assessment of stored red blood cells probed using atomic force microscopy. Anat Res Int. 2014; Article ID 869683:5pp. DOI:10.1155/2014/869683

Printed book of Proceedings (or part of printed Book):

On Russian

Shvedavchenko AI, Oganesyan MV, Kalandarishvili MO, Feduleev MN. Anatomicheskie osobennosti chrevnogo stvola. V kn.: Anatomiya cheloveka: vchera, segodnya, zavtra. Mater. konf., posvyashch. 250-letiyu kafedry anatomii cheloveka Pervogo MGMU im. I.M. Sechenova (1764-2014). Moskva: PMGMU; 2014:139-140.

On English

Brown K, Cartmill M. Chapter 12. 75 Years of the Annual Meetings of the American Association of Physical Anthropologists, 1930-2004. In book: Histories of America Physical Anthropology in the Twentieth Century. Ed. by M.A. Little and K.A.R. Kennedy. Lexington Books: Lanham-Boulder-N-Y-Toronto-Plymouth; 2010:221-233.

Open access of Proceedings (or part of Book):

On Russian

Andreeva IV, Vinogradov AA, Orzulova EV. Osobennosti v raspredelenii diploicheskikh ven temennoy kosti cheloveka po dannym morfologicheskikh issledovaniy $\mathrm{v}$ zavisimosti ot pola $\mathrm{i}$ formy cherepa. V kn.: Materialy IV Mezhregional'noy nauchnoy konferentsii «Aktual'nye problemy meditsinskoy nauki i obrazovaniya»: elektronnoe nauchn. izdanie. Penza: FGUP NTTs «Informregistr», Depozitariy elektronnykh izdaniy; 2013:9-16. URL: http://dep_anatom.pnzgu.ru/files/dep_anatom.pnzgu.ru/conference/aktualnye_problemy_medic inskoy_nauki_i_obrazovaniya_2013.pdf

On English

Khayrullin RM, Safiullina AF. The frequency of forms of the talus in modern Russians population/ In: 111th Annual Meeting Deutsche Anatomische Gesellschaft, September 23-25, 2015. Würzburg, Germany, 2015: Poster 29. DOI: 10.13140/RG.2.1.4446.6643

Book:

On Russian

Avtandilov GG. Morfometriya. Rukovodstvo. Moskva: Meditsina; 1990. 384s.

On English

Arias JL. Nanotechnology and Drug Delivery. Volume 1: Nanoplatforms in Drug Delivery. Boca Raton-London-New York: CRC Press Taylor\&Francis Group; 2014. 368pp.

Web-sources: 
On Russian

Speranskiy VS, Goncharov NI. Ocherki istorii anatomii [Tekst]: nauchnoe izdanie/ V.S. Speranskiy, N.I. Goncharov. Volgograd: Izdatel'; 2012. 216 s. URL: http://www.vounb.volgograd.ru/elibrary/book/goncharov/GoncharovOcherki_istorii_anatomii.pdf

On English

Anatomy Atlases. An anatomy digital library curated by R.A. Bergman. Atlas of Human Anatomy. Translated by R.A. Bergman and A.K. Afifi. The University of Iowa. 2014. URL: http://www.anatomyatlases.org/atlasofanatomy/index.shtml

11. In the section of the information about authors should be specify (for each author): full name, position and affiliation, academic status, academic degree, postal address, telephone number, e-mail, personal signatures of all authors. Additionally, authors if necessary may use other (not listed) headings and subheadings of sections. Author's information and its (their) signature(s) should be printed at the end of the manuscript, accordance which the author legally confirms its personally consents, and in the case of publication, also the personally consents to the placement of the article and the author's online-information in the Russian Science Citation Index on the platform of the Scientific Electronic Library and/or online publication on the journal's website. The page with personal signatures of the authors may be presented as scan-copy in *.pdf or any picture-files.

12. Finally, the form of the sent material should be kept in the archive (*.zip, *.rar, 7-zip), and should have the following files with names:

a. A file, which contain of the text of the article, it is recommended to call as surname of author", i.e.: Surname_doc or Surname_et_al_.doc. The end page(s) of this file should be containing the author(s) information and picture(s) with author(s) signature(s).

b. File(s) containing of the Tables should be named such as Surname_Table_1.doc, Surname_Table_2.doc, etc.

c. File(s) containing of the illustrations should be named such as Surname_Fig_1.jpg, Surname_Fig_2.jpg or Surname_Fig_A.jpg, Surname_Fig_B.jpg, etc.

d. The file(s) containing the designations for illustration: Surname_Design_Fig_1.doc, Surname_Design_Fig_2.doc, etc.

e. If case is of separate scan-copy of end page(s) of the text of the article with author information and author(s) signature(s), should be sent corresponding file with the title: Surname_Author_Inform.pdf.

f. File with the scan-copy of payment check: Surname_Payment.pdf or Surname_Payment.jpg.

g. Additional documents and materials at the initiative and discretion of the author (statistical files, additional tables, figures, photographs, certificates of grants, etc.) which are necessary to confirm the relevance and validity of the research.

13. The author should be ready for the any request of editors or reviewers to provide additional documents and information.

14. In the case of an incorrect translation English of the title, of details of the authors, of abstract and keywords, the total mismatch resume and list of references to the requirements of the journal, the lack of the transliteration of the titles of the sources in the Cyrillic alphabet into English, the editors deny to authors in the indexing of articles and summaries of all international indexers, due to the need to perform terms of the respective contracts. Subject to all the other rules of the journal article may be published only in the printed version of the journal without presentation the online version of the article on the journal's website.

15. All e-mail correspondence of the author(s) and of the editors has the same legal force as the exchange of relevant standard documents. 